\title{
Some investigations of isostasy and Earth's contraction
}

\author{
E. N. LYustikh $\left({ }^{*}\right)$
}

Ricevuto il 7 dicembre 1960

\section{I. - CONTRACTION HYPOTHESIS.}

1. Seismic and gravity investigations have revealed that the Earth's crust is quite different on continents and under oceans; therefore the continents and the ocean basins cannot be upheavals and subsidences due to the contraction of the Earth. So the contraction hypothesis fails in the explanation of major features of the globe.

Vertical movements play the leading part in the evolution of the Earth's crust and they change sign in time. It is inexplicable from the standpoint of Earth's contractions. Continents grow laterally, evidently new portion of continental crust is being formed. No explanation for this can be given by contraction hypothesis.

2. Assuming contraction hypothesis the diminution of the Earth's surface from geological data is at least 5 per cent during each tectonic cycle. As at least $\mathbf{1 5}$ cycles have passed since the Earth's formation the total shortening would be half of the whole surface, which is impossible.

3. Every great circle of the Earth is to shorten equally. Nevertheless, as we see from the globe, the shortening would be very different, if it were. E. g. the circle consisting of meridians $15^{\circ} \mathrm{W}$ and $165^{\circ} \mathrm{E}$ has no indication of significant shortening, while along the circle $90^{\circ} \mathrm{W}$, $90^{\circ} \mathrm{E}$ there was a great shrinkage (mainly on account of the mountain buildings in Asia). In general, there are too few great structures stretching latitudely on the globe. It is inconsistent with the idea of the Earth's uniform shrinkage.

4. The contraction hypothesis supposes that folded mountains are due to the squeezing a geosyncline (orogen) between two platforms

(*) Paper read at the Helsinky Assembly of the I.U.G.G., 1960. 
(cratons). Let us consider a cross section from the middle axis of a symmetrical platform to the middle axis of a geosyncline (fig. 1).

We may neglect the elastic strain of the platform. Two cases are to be considered. The first one is a case of elastic substratum or little contraction ( $\mathrm{I}$ on the fig. 1 ); the second case is a case of plastic substratum and great contraction (II on the fig. 1). In the first case the limit of elasticity is nowhere passed over. Under the platform $A$ there is a transitional layer $B$, tangential stress in which exists, and the rate of thermical contraction grows with depth untill the full rate of contraction is reached in the layer $C$.

In the second case (II on the fig. 1) the surface of shearing separates the platform $A$ from the layer of full contraction $C$. We may suppose the tangential stress on this surface to be equal to the fundamental strength of the substratum. While the layer $C$ contracts to its middle line $O$ the platform $A$ crumples the geosyncline $F$, so the latter exerts some pressure upon the side of platform. Nevertheless the maximum stress must be in the centre of platform $O$ as the analysis has shown. While the contraction goes on, the stress grows up, and the platform must be destroyed in its middle after all. The larger is a platform the greater is the stress in the middle, therefore for any given amount of contraction the maximum length of the platform may be established which can exist without crushing. Let us denote (fig. 1):

$O$ - middle of the platform and origin of coordinates (only abscissas are considered),

$a$ - abscissa of the edge of the platform $A$,

$c$ - abscissa of the edge of the layer $C$ after contraction,

$h$ - thickness of the platform $A$,

$H$ - thickness of the transitional layer $B$,

$\mu$ - crushing horizontal stress for the platform $A$,

$\nu$ - pressure of the platform $A$ upon the geosyncline $F$,

$G$ - rigidity of the layer $B$,

$\sigma$ - fundamental strength of substratum,

$$
k=\frac{a-c}{a} \text { amount of contraction. }
$$

The limit of $a$ is:

$$
\begin{aligned}
& \text { in the first case } a<\sqrt{2 h H \frac{\mu-\nu}{G k}} \text {, } \\
& \text { in the second case } a<h \frac{r-v}{\sigma} .
\end{aligned}
$$


You see, in the case of great contraction (II.) the limit is independent of the amount of contraction $k$.

Being pressed laterally the material of a geosyncline undergoes both squeezing upwards and folding. The upward protruding makes tension of the uppermost strata and so prevents from folding. Hence the maximum folding must be at the bottom of geosyncline, and it may occur at the top only if the thickness of the geosyncline is suffi-

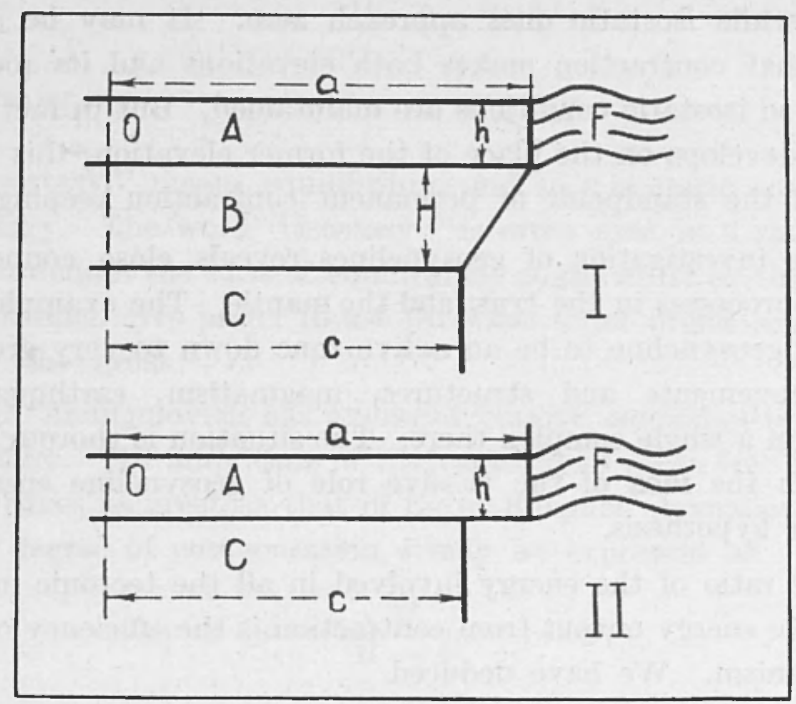

Fig. 1.

ciently small in comparison with its breadth. Even the allowance being made for denudation away of the upper ten kilometers, the folded structure cannot be exposed if the thickness of the platforms working as pistons exceed $30 \mathrm{~km}$. (for the usual breadth of folded zone). Thus we take

$$
\begin{aligned}
& h=30 \mathrm{~km}, \\
& H=1000 \mathrm{~km}, \\
& \mu=6000 \mathrm{~kg} / \mathrm{cm}^{2} \\
& \nu=4200 \mathrm{~kg} / \mathrm{cm}^{2}, \\
& G=5 \times 10^{5} \mathrm{~kg} / \mathrm{cm}^{2}, \\
& \sigma=150 \mathrm{~kg} / \mathrm{cm}^{2}, \\
& h=0.04 \text { in the Cenozoic Era. }
\end{aligned}
$$

This gives the maximum length of a platform $2 a$

in the first case $2 \mathrm{a}<150 \mathrm{~km}$, in the second case $2 \mathrm{a}<720 \mathrm{~km}$. 
In reality platforms exist larger than $2000 \mathrm{~km}$. It needs $\sigma<9$ $\mathrm{kg} / \mathrm{cm}^{2}$, which is too small.

5. Let us suppose the major features of the surface relief on the globe are due to warping in the course of contraction. In such a case gravity anomalies both Bouguer and isostatic must be positive on elevations and.negative in depressions. It is generaliy known that as a rule Bouguer anomalies are negative on elevations and positive in depressions, while isostatic ones approach zero. It may be suggested, however, that contraction makes both elevations and its roots simultaneously, so isostatic conditions are maintained. But in fact a depression often develops on the place of the former elevation; this is inexplicable from the standpoint of permanent contraction keeping isostasy.

6. The investigation of geosynclines reveals close connection between the processes in the crust and the mantle. The example of island arcs shows geosyncline to be an active zone down to very great depth. Specific movements and structures, magmatism, earthquakes, and gravity form a single complex there. The situation is thoroughly inconsistent with the idea of the passive role of geosyncline ensuing from contraction hypothesis.

7. The ratio of the energy involved in all the tectonic movements to the whole energy output from contraction is the efficiency of contraction mechanism. We have deduced

$$
\hat{\rho}<\frac{2(\mu-2 \nu)}{3 D g R}
$$

where $\beta$ - efficiency of contraction mechanism,

$D$ - density of the Earth's crust,

$g$ - mean gravity acceleration in the crust,

$R$ - radius of the Earth,

and $\gamma, \nu$ are expressed in dynes per square centimetre.

Taking $D-3 \mathrm{~g} / \mathrm{cm}^{3}$ and $\mu, \nu$ as before we get $\beta<0.005$.

The power of all the tectonic processes $T$ may be estimated from the total power of seismic waves. This gives $T>10^{26} \mathrm{erg} /$ year.

Taking $\beta$ into account the shortening of the Earth's radius must be of order $10^{-\theta}$ a year. Nevertheless the astronomical data (the retardation of the Earth's rotation) prove the shortening to be no more than $7 \times 10^{-11}$ if any (after N. N. Pariysky). Yet the latter figure cannot be due to the cooling of the Earth since it needs the heat escape from the Earth's ball $>2.8 \times 10^{29} \mathrm{erg} /$ year, i. e. an order greater than it is. 
The proper calculation of the Earth's thermal history performed by $H$. A. Lubimova and by B. J. Levin and S. V. Mayeva prove the temperature in the globe except the outermost thousand kilometers has been growing up, and consequently, no thermal contraction can be at all.

As a conclusion it may be said that the contraction hypothesis is untenable from all points of view.

\section{II. - Isostasy.}

8. "Isostasy" means equilibrium, and so "isostatic equilibrium" is a tautology. The word "isostasy" is often used in a rather vague sense, as to denote the idea of equilibrium of the crust or the tendency to its performing. We prefer to use the word in its literal sense "equilibrium of the crust".

9. I. D. Zhongolovich has averaged gravity anomalies in each tendegrees-square. The amplitude of the variation of mean free air anomalies is ten times as great as that of mean Bouguer anomalies. The approximate degree of compensation $i$ may be expressed as

$$
i=\frac{B}{B-F},
$$

Where $B$ - Bouguer anomaly,

$F$ - free air anomaly.

We have the averages for all the continents $B=-97 \mathrm{mgal}$, $F=+9 \mathrm{mgal}$; hence $i=0.91$. For all the oceans $B=+230 \mathrm{mgal}$, $F=-3 \mathrm{mgal}$, and hence $i=0.99$.

Taking these values into account we may say that in general the Earth's crust is compensated to within about 10 per cent.

10. Often the attempts are made to determine the regionality of isostasy and the normal thickness of the crust (or the depth of compensation) from gravity data only. As a rule such attempts cannot give trustworthy results. In the first place, isostatic anomalies depend only on some function of both the radius of regionality and the depth of compensation, and it is impossible to distinguish the contribution of each. And yet this function is not learned at all.

In the second place, the very criteria for selection of the "best" values are doubtfull. The simplest criterion is the approaching of mean anomaly to zero. It may be true on an ancient plain, where tectonic 
forces have been exhausted long ago. But the compensation is a flat horizontal slab in this case, and its parameters are indeterminable. In highlands, on the contrary, the effect of compensation may vary very much with its parameters, but at the same time we cannot expect the mean anomaly to be low there, since the tectonic forces upset isostasy while making mountains.

Another test is as foliows. For any set of parameters we may approximate the observed anomalies by a straight line.

$$
g=a+b h
$$

where $g$ - isostatic anomaly,

$h$ - height of the station,

$a, b$ are to be calculated by the least square method.

It is believed that the combination of parameters giving the least value of $b$ is the nearest one to the reality. This may be true only if the compensation is really fuli, which we do not know and cannot do. And yet if it were full, $a$ must be zero, which is not the case mostly. So this criterion fails too.

11. Some authors have calculated the viscosity (or "pseudo-viscosity") of the substratum from the rate of the postglacial uplift of the Fennoscandia or Canada tectonic shield. A. D. Arkhangelsky and $H$. Stille insist the uplift is caused by powerfull tectonic forces which have been acting long before the glaciation as well. $H$. Jeffreys points out that many other places do not rise having the same gravity anomalies. This objection is very strong, as isostatic anomalies exactly indicate the amount of extra load.

Of course, the isostatic forces may take part in the uplifting, but their share is unknown, and therefore any numerical calculation is misleading.

12. The topographic anomalies (i. e. the Bouguer anomalies with terrain correction) are best suitable for tectonic interpretation because they are affected by all the density anomalies. In particular, they give almost immediately the approximate relief of the bottom of the Earth's crust, whereas the isostatic anomalies require complicated calculations. Indeed, firstly the bottom relief of the crust is to be established which corresponds with a zero isostatic anomaly and then it is to be modified according to the real anomalies. As E. N. Lyustikh has pointed out in $1947, \mathrm{~F}$. A. Vening-Meinesz had missed the first stage and, as a result, has obtained a great root (buckling) where none exists (cf. Ch. Tsuboi). 
13. The isostasy is not a leading factor in the evolution of the Earth's crust since the establishment of equilibrium is a passive process and leads to quieting. Only a disturbing force can be active, as even C.E. Dutton has pointed out. Observations very often reveal tectonic movements going against isostasy. But the greater is the tectonic disturbing the greater is the isostatic counteraction and the latter puts a limit to the former; thus no isostatic anomaly is observed beyond $\pm 300 \mathrm{mgal}$.

The tectonic forces, as a rule, change sign many times. If such a changeable force weakens and damps gradually, the movements have to stop at the position of isostasy.

\section{$S U M M A R Y$}

The contraction hypothesis is discussed from the geological, gravimetric, mechanical, and geothermic point of view. The role of isostasy in the geotectonics evolution is considered.

\section{RIASSUNTO}

Si discute l'ipotesi della contrazione dal punto di vista geologico, gravimetrico, meccanico e geotermico. Si considera il ruolo dell'isostasi nell'evoluzione geotettonica.

\section{REFERENCES}

Arkhangelskt A. D), (Архкангельсии А. Д.), Тр. Научно-иссл. ин-та геол. $и$ минералогии, I 1933.

Dutron C. E., Bull. Nat. Res. Council, 78, Washington, 1931.

JefFreys H., The Earth. 4th ed., Cambridge, 1959.

Ievin B. J., Mayeva S. V., (Левин Б. Ю., Маeba С. В.), Нзв. Акад. Наук СССР, серия геофиз. ‥ 2, 1960.

Lubimova H. A., Geophys. J., 1, 2, (1958). 
Lyostikн E. N., (Люстих Е. Н.), Тр, Ин-та теоретич. геофизики, АН СССР, 3, 1947. Докл. Акад. Наук СССР, 65, N. 6, 1949. Тр. Геофиз, ин-та, АН CCCP, N. 26 (153), 1955. Abstr. rep. XI Gen. Ass. IUGG, Int. Ass. Geod. Moscow 1957. Tp. Геофиз. ин-ma, АН СССР, N. 38, (165), 1957 Тр. Нн-та физики Земли, АН СССР, N. 3, (170), 1958.

Pariysky N. N., (Париискии Н. Н.), Тр. Геофиз. ин-ma, N. 26, (153), 1955. Stille H., Publ. Inst. Seismologique, 32, Leningrad, 1933.

Tsuboi Ch., Verh. kon. Nederl. Geol.-Mijn. Genootschap, "Geol. Serie", 18, Gedenkboek F. A. Vening-Meinesz, 1957.

Vening-Meinesz F. A., Gravity expeditions at sea 1923-1932, 2, Delft. 1934.

Zноngolovich I., (Жонголович И.), Тр. Нн-та теоретич. астрономии, АН CCCP, 3, 1952. 